\title{
EDGE: 20 Essays on Contemporary Art Education
}

Anette Göthlund, Helene Illeris,

Kirstine W. Thrane (Eds.)

Copenhagen: Multivers Academic, Tanum 383 pages (2015)

\section{Art education moving things to the edge, or paths to knowledge that are not safe but experimental}

Connections between art and education are explored in the anthology EDGE. This book is a result of the Nordic-Baltic network CAVIC (Contemporary art and visual culture in education) activities 2010-2012. The essays in EDGE can be read as an attempt to bring about a shift from knowing and being to doing and becoming in art education. One motive for creating the CAVIC network was related to the political aspects of art education. The network noticed that the social engagement of critical art education from the 1970 s and 1980 s was fading. In education neo-liberal thinking focuses on the pupils' individual and strictly defined achievements, and hence the network application text for CAVIC concluded that there is a need for a reformulation of the political role of art education. The editors write that

/.../ the essays explore art education from perspectives that are critical in the sense that they discuss existing theories and practices and propose changes and improvements to these; political in the sense that they suggest what art education might look like in the future; and performative in the sense that many of these essays enact new approaches to the practice of art education through processual and collaborative forms of working. (p. 15)

Even if the name of the book could give the reader an impression that the authors are not so central in the field of art education, this is not the case. Researchers, artists and students at the forefront of art education have written in this book. The essays are written from inside the field and from contemporary practices, and 


\section{A.-L. Østern}

each essay explores «how art education can be questioned and understood as a meaningful activity here and now» (p. 15).

When I hold the anthology in my hands I notice that it has a lay out, that indicates something processual: from the spiral binding to the choice of visual markers of key words and authors randomly presented according to the alphabet with use of first names, and with use of different colours for each writer for texts written in collaboration. For me as a reader it functions like a reading contract, or a reading instruction. It is a bit challenging to my habits of reading, but it is first and foremost trigging the curiosity. So let's see what is in this essay collection.

\section{Possible edges - finding ways to open different perspectives on contemporary art education}

The editors comment on the title of the book, that it indicates a movement away from trying to establish a centre. They want to explore possible edges, as a line dividing here form there and the known from the unknown.

Article 14 written by Juha Varto and printed with larger fonts than the other articles seems to be a leading text, called Art education: the future made by choice. Varto writes:

Art education seems to be at a turning point: The more pragmatic the school system becomes, the less space there is for art. Even if art is appreciated in speech, in practice it is taken as a vehicle that makes learning more effective in topics that really seem to matter, namely those effectual for industry and commerce. The question is if we are ready to accede to acting as per the effiency of alien ambition, to help the technical and informative subjects of school. (p. 263).

Varto writes a critical text saying that: «We live our lives as if nothing has really happened» (p. 265). He outlines what needs to be done within research in art education, especially better articulation of the practice and its foundation. He also mentions that a fierce analysis of concepts is needed. According to Varto the art educators might use «any concept he or she happens to catch in discussion». Varto's text seems to be presented orally, like a key note, and the final words are about how art education can make a difference through intensified cooperation:

We need a new art educational movement that is freed from Enlightment ideology and its shortcomings. The human condition and a good life are always negotiable and under constant change, but only by keeping to our own idea of what they might be may we take part in the negotiation. (p. 275).

In an introducing article Göthlund, Illeris and Thrane define the contemporary field of art education as everything that can happen when combining the two complex practices of 'art' and 'education' within different contexts and from different angles. They present three ways of looking at art education:

1) As an object of study;

2) As a practice. A way to approach and transform the world through artistic educational activities; 
3) As a perspective, a way of sensing, understanding and influencing the world reflectively.

In their article they connect these ways of looking at art education with the themes of the essays in the book. The introduction also presents new approaches to research in art education. This introduction is very interesting and informative. They mention that only a small number of the essays in the volume engage with art education as a school subject. They suggest that one reason for this might be that the political dilemma might have a paralysing effect on reserachers in art education who would like «to experiment with new ideas and practices within a school context.» (p. 25).

\section{Poststructuralism, posthumanism and new materialism}

Through many of the essays some common concepts are in frequent use. Collaboration and polyphonic writing are two of them, relational aesthetics and performativity other concepts in use. Gilles Deleuze and Felix Guattari have served as theoreticalphilosophical inspiration through concepts like rhizome and above all becoming. Process and exploration are more interesting than product in these essays. Donna Haraway, Karen Barad and Lenz Taguchi are connected with diffractive thinking. Diffraction is unique to all kinds of wave behaviour. It might concern when human bodies interact with material in nature. Taguchi is also quoted in Ulla Lind's essay (no. 20) regarding intra-active learning. Students in her study intra-act with the natural environmentwind, branches, grass, sound, snow and light.

\section{Art and education in a broad sense, and so what?}

The encounter between art and education has been the red thread throughout the articles. The reader has been drawn into explorative processes. Some of the guiding questions for the CAVIC project have been:

How can artistic methods, theories and practices be used and reflected in educational contexts?

How can educational methods, theories and practices be used and reflected in artistic contexts?

In which ways does art education influence and help us understand and analyse contemporary cultural, social and aesthetic practices?

The book presents serious attempts to explore the questions posed, and the book is impressive both in quantity and quality. For the CAVIC group it must have been empowering. For reserachers, artists and students within other arts the anthology can serve as an example of how the cutting edge questions are approached in art education and visual culture pedagogy.

Anna-Lena Østern 